\title{
PENGEMBANGAN PEMBELAJARAN DENGAN PENDEKATAN PMRI BERBANTUAN GEOGEBRA UNTUK MEMBANGUN PEMAHAMAN KONSEP TRANSFORMASI GEOMETRI
}

\author{
${ }^{1}$ Arumella Surgandini, ${ }^{2}$ Pinta Deniyanti Sampoerno, ${ }^{3}$ Anton Noornia \\ ${ }^{1}$ STKIP Surya Tangerang, Jalan Imam Bonjol No.88, Bojong Jaya, Kec. Karawaci, Kota Tangerang, Jawa Barat \\ 15115 , Indonesia \\ ${ }^{2,3}$ Universitas Negeri Jakarta, Jl. Rawamangun Muka, RT.11/RW.14, Rawamangun, Kec. Pulo Gadung, Kota \\ Jakarta Timur, Daerah Khusus Ibukota Jakarta 13220, Indonesia \\ e-mail: arumella.surgandini@ stkipsurya.ac.id
}

\begin{abstract}
Abstrak
Peserta didik matrikulasi di STKIP Surya Tangerang mengalami kesulitan dalam mempelajari transformasi geometri. Masalah pemahaman konsep transformasi geometri yang dialami peserta didik STKIP Surya perlu diatasi karena sebagai calon guru, peserta didik di STKIP Surya dituntut untuk memahami konsep matematika dengan baik agar kelak dapat mengajarkan materi dengan baik pula. Penelitian ini bertujuan untuk mengembangkan teori instruksional lokal guna membangun pemahaman konsep peserta didik pada materi transformasi geometri dengan menggunakan pendekatan PMRI berbantuan GeoGebra. Penelitian ini terdiri dari 8 pertemuan dengan subjek penelitian 6 peserta didik yang memiliki kemampuan awal berbeda berdasarkan materi prasyarat. Metodologi yang diterapkan adalah design research yang meliputi tahap preparation and design, teaching experiment, dan retrospektif analysis. Teknik pengumpulan data yang digunakan, yaitu pensil dan kertas, wawancara, serta perekaman video. Instrumen penelitian dalam pengumpulan data adalah hipotesis lintasan belajar, lembar aktivitas, lembar kerja, lembar observasi, lembar wawancara dan tes kemampuan pemahaman konsep. Hasil analisis retrospektif menunjukkan bahwa penerapan PMRI berbantuan GeoGebra dengan menggunakan konteks peraturan baris-berbaris dapat menumbuhkan dan meningkatkan pemahaman konsep transformasi geometri peserta didik.
\end{abstract}

Kata Kunci: design research, PMRI, GeoGebra, pemahaman konsep, transformasi geometri

\begin{abstract}
As prospective teacher, students of STKIP Surya Tangerang are required to understand the mathematics concept well. In order to achieve this, the students supposed to take matriculation program which include basic mathematics as one of the subjects. However, they still had difficulties in understanding some mathematical concept, namely the concept of transformational geometry. This study aims to develop local instructional theory in order to establish students' conceptual understanding of transformational geometry material using PMRI approach utilizing GeoGebra. This study consisted of nine sessions with six research subjects. Those subjects are students who had different initial abilities which is known from the prerequisite material. The method used in this study is design research of which the stages are preparation and design, teaching experiment, and retrospective analysis. The data collected using student's written work, interviews, also video recording. The Instruments of this study consist of hypotheses of learning trajectories, student's activity sheets, worksheets, observations sheets, interviews sheets, and concept comprehension tests. The results from retrospective analysis show that the implementation of PMRI utilizing GeoGebra on drill commands context can foster and enhance student's conceptual understanding of transformational geometry.
\end{abstract}

Keywords: research design, PMRI, GeoGebra, conceptual understanding, geometry transformation

\section{PENDAHULUAN}

Kemampuan memahami konsep dan menerapkan prosedur matematika dalam kehidupan sehari-hari merupakan salah satu tujuan pembelajaran matematika yang tertuang dalam Permendiknas Nomor 22 Tahun 2016. Memahami matematika bukan berarti 
menghafal rumus, definisi, atau teorema (Alfeld, 2004). Peserta didik diharapkan mampu memahami konsep-konsep matematika, sehingga dapat mengaitkan dan menjelaskan hubungan antar konsep serta dapat mengaplikasikan konsep tersebut. Pemahaman berada pada tingkat kedua dalam ranah kognitif pada taksonomi Bloom. Hal ini menunjukkan bahwa pemahaman konsep merupakan landasan penting yang perlu dimiliki peserta didik agar mereka mampu berkembang ke tingkat berpikir yang lebih tinggi.

Geometri merupakan satu dari lima cabang ilmu matematika yang dipelajari pada pelajaran matematika di sekolah (Permendiknas No.22 Tahun 2016). Salah satu pokok bahasan geometri pada pelajaran matematika di sekolah adalah transformasi geometri, yang meliputi translasi, refleksi, rotasi, dan dilatasi. Pemahaman terkait konsep transformasi geometri ini penting untuk dimiliki peserta didik karena merupakan salah satu landasan penting pemecahan masalah dalam kehidupan. Namun, kesulitan terkait pemahaman konsep geometri ini masih dialami siswa. Kesulitan ini tercermin dari kesalahan peserta didik dalam melakukan transformasi geometri (Hollebrands, 2004; Özerem, 2012; Minnesota STEM Teacher Center, 2014).

Kesulitan terkait transformasi geometri juga terlihat pada hasil observasi peserta didik di STKIP Surya. Kesulitan tersebut diantaranya tercermin dalam kesalahan peserta didik ketika menyelesaikan soal translasi, kesalahan dalam menggambarkan hasil refleksi objek dengan garis $y=x$ sebagai cermin, kesalahan dalam menyelesaikan soal terkait rotasi, dan ketidakmampuan peserta didik menyelesaikan soal terkait dilatasi. Lebih jauh, cara peserta didik menyelesaikan soal dengan menggambar pada bidang Cartesius menunjukkan bahwa peserta didik belum mencapai tahap operasional formal. Selain itu, hasil angket yang diberikan pada peserta didik menunjukkan bahwa $77 \%$ peserta didik menyatakan bahwa mereka mengalami kesulitan dalam mempelajari transformasi geometri. Alasannya, pada materi ini banyak gambar dan rumus yang ditulis di papan tulis. Hafalan rumus yang tidak disertai pemahaman konsep ini membuat peserta didik lupa dengan rumus-rumus yang dihafal ketika materi yang dipelajari telah berlalu. Selanjutnya, dari hasil wawancara diketahui bahwa peserta didik kesulitan dalam merepresentasikan tranformasi geometri secara visual dan mereka memerlukan alat bantu untuk menggambarkan transformasi geometri.

Masalah pemahaman konsep trasformasi geometri yang dialami peserta didik STKIP Surya perlu diatasi. Karena, sebagai calon guru, peserta didik di STKIP Surya dituntut untuk memahami konsep matematika dengan baik agar dapat mengajarkan materi dengan baik pula. 
Untuk mengatasi masalah tersebut, perlu dilakukan kegiatan pembelajaran yang lebih bermakna bagi peserta didik sehingga mereka tidak hanya menghafal rumus-rumus saja, tetapi memahami konsep dari apa yang dipelajari. Salah satu pendekatan pembelajaran yang menekankan pada pembelajaran yang bermakna, mempersiapkan peserta didik menemukan dan memahami konsep, serta membangun tahap operasional formal peserta didik adalah pendekatan Pendidikan Matematika Realistik Indonesia (PMRI). Hal ini karena PMRI bertumpu pada konteks realita dalam kehidupan sehari-hari peserta didik sehingga matematika menjadi hal yang tidak abstrak dan tidak asing bagi mereka. Konteks realita terkait transformasi adalah Peraturan Baris-Berbaris (PBB) yang dilakukan oleh Pasukan Pengibar Bendera (Paskibra) ataupun Resimen Mahasiswa (Menwa) saat melakukan barisberbaris. Konteks tersebut tidak asing bagi peserta didik STKIP Surya sehingga dapat digunakan sebagai konteks dalam pembelajaran dengan Pendekatan PMRI. Penelitian lain yang menerapkan PMRI untuk mengatasi masalah serupa menunjukkan hasil yang positif, diantaranya penelitian Nugraheni dan Sugiman (2013), Albab dkk (2014), Novrika (2016).

Namun, penerapan pembelajaran yang bermakna tidaklah cukup untuk mengatasi masalah pemahaman konsep peserta didik STKIP Surya terhadap transformasi geometri. Diperlukan alat bantu yang dapat memudahkan peserta didik merepresentasikan transformasi geometri secara visual. Hal ini sejalan dengan yang dinyatakan Özerem (2012) bahwa salah satu solusi untuk mengatasi kesalahan yang dilakukan peserta didik dalam pembelajaran transformasi geometri penggunaan alat bantu visual oleh pengajar agar dapat mengajar materi transformasi geometri secara lebih mendetail. Beberapa penelitian sebelumnya menunjukkan keefektifan alat bantu visual dalam meningkatkan pemahaman konsep matematika khususnya terkait transformasi geometri, diantaranya penggunaan Geometer's Sketchpad (Hollebrands, 2004), penggunaan Cabri (Guven, 2012), penggunaan GeoGebra (Saha dkk, 2010; Larijani dkk, 2012). Dari ketiga jenis alat bantu tersebut, GeoGebra merupakan alat bantu yang telah dikenal peserta didik STKIP Surya. Penggunaan GeoGebra dalam pembelajaran transformasi geometri tentu dapat dijadikan alternatif cara untuk mengatasi kesulitan yang dialami terkait materi tersebut. Geogebra memiliki dua belas construction tools, salah satunya adalah tools transformasi geometri sehingga GeoGebra cocok digunakan sebagai alat bantu pada penelitian ini. Penerapan pembelajaran bermakna melalui pendekatan PMRI yang disertai penggunaan alat bantu GeoGebra dapat dijadikan alternatif solusi untuk membangun pemahaman konsep peserta didik di STKIP Surya. 


\section{METODE PENELITIAN}

Jenis penelitian yang digunakan adalah design research karena tujuan yang hendak dicapai adalah pengembangan teori instruksional lokal guna membangun pemahaman konsep peserta didik pada materi transformasi geometri dengan menggunakan pendekatan PMRI berbantuan GeoGebra. Design research sendiri merupakan kajian yang sistematis dan berkelanjutan tentang merancang, mengembangkan, dan mengevaluasi intervensi pendidikan seperti program, proses belajar, lingkungan belajar, materi belajar dan pembelajaran, produk, dan sistem sebagai solusi terhadap permasalahan masalah di pendidikan (Gravemeijer \& Eerde, 2009; Baker \& Eerde, 2013; Plomp, 2013). Penelitian design research dibangun dari tiga tahapan, yaitu preparation and design, teaching experiment, dan retrospective analysis. Berikut ini diberikan penjelasan dari masing-masing tahapan.

\section{Preparation and Design}

Inti dari tahap ini adalah persiapan dengan membuat desain pembelajaran yang terdiri dari aktivitas pembelajaran yang sesuai dengan tujuan pembelajaran yang akan dicapai serta hipotesis proses pembelajaran yang akan terjadi. Desain pembelajaran ini akan termuat dalam Hipotesis Lintasan Belajar (HLB).

\section{Teaching Experiment}

Pada tahap kedua ini, HLB yang telah didesain pada tahap pertama dilaksanakan di kelas. Pada tahap ini pula dikumpulkan data-data penelitian yang digunakan untuk menganalisis aktivitas pembelajaran yang telah dilakukan.

3. Retrospective Analysis

Pada tahap ketiga ini, seluruh data yang telah terkumpul dianalisis. HLB yang didesain dibandingkan dengan proses pembelajaran aktual peserta didik. Akhirnya, hasil analisis yang diperoleh digunakan untuk menjawab pertanyaan penelitian yang diajukan.

\section{HASIL DAN PEMBAHASAN}

\section{Hasil Eksperimen Mengajar}

Hasil eksperimen mengajar merupakan bagian yang memuat deskripsi secara terperinci tahap kedua, yaitu tahap pelaksanaan pengajaran yang dilakukan dengan menggunakan pendekatan PMRI berbantuan GeoGebra. Pada tahap ini juga dilakukan analisis retrospektif proses pembelajaran di setiap pertemuan sehingga diperoleh kelebihan dan kekurangan proses pembelajaran yang terjadi. Secara garis besar, aktivitas pembelajaran dimulai dengan konteks. Kemudian peserta didik berdiskusi mengerjakan Lembar Aktivitas untuk melakukan penemuan model of dan model for. Perwakilan peserta didik akan mempresentasikan hasil Prima, Vol. 3, No. 2, Juli 2019, 85-102. 
diskusi kelompok. Pengajar sebagai fasilitator akan memberikan bimbingan selama diskusi kelompok maupun diskusi kelas guna mengarahkan peserta didik ke penemuan dan kesimpulan. Kegiatan berlanjut dengan pengerjaan Lembar Kerja secara mandiri oleh peserta didik. Perwakilan peserta didik bergantian membahas hasil kerjanya. Pembelajaran ditutup dengan menyimpulkan bersama. Kegiatan tersebut dimanfaatkan oleh pengajar untuk mengkonfirmasi pemahaman konsep peserta didik.

\section{a. Pertemuan Pertama}

Aktivitas pada pertemuan pertama adalah aktivitas menemukan dan memahami sifat-sifat translasi, refleksi, rotasi, dan dilatasi. Konteks yang digunakan adalah Peraturan BarisBerbaris (PBB) atau sering disebut aba-aba baris-berbaris yang dilakukan oleh Resimen Mahasiswa (Menwa) dalam kegiatan baris-berbaris. Video baris-berbaris Menwa ditayangkan sebagai titik awal pemahamn konsep. Aktivitas selanjutnya adalah praktik baris-berbaris yang dilakukan langsung oleh peserta didik kemudian perubahan posisinya digambar dengan GeoGebra seperti pada Gambar 1.

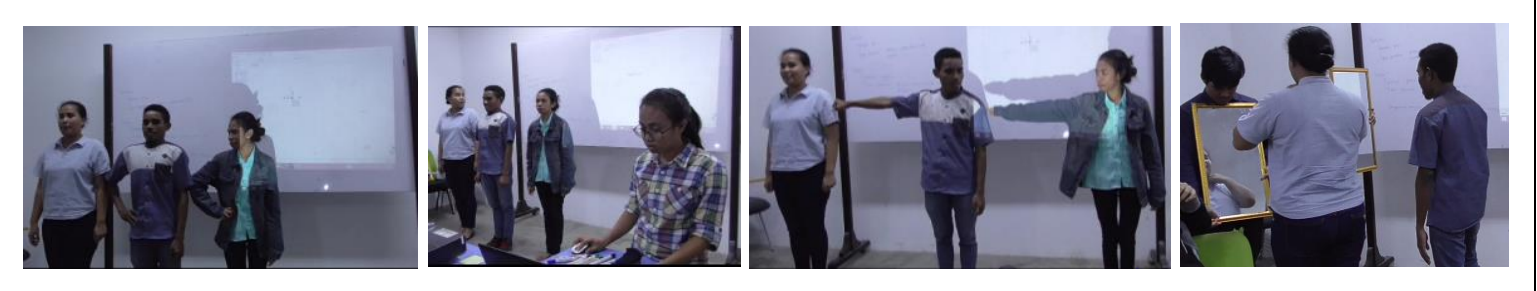

Gambar 1. Peserta Didik Mempraktikkan Aba-Aba yang Berkaitan dengan Dilatasi

Aktivitas selanjutnya diskusi mengerjakan Lembar Aktivitas. Peserta didik paham abaaba baris berbaris sehingga dapat menemukan sediri sifat-sifat transformasi geometri. Untuk refleksi, peserta didik mempraktikkan kegiatan bercermin yang dilakukan Menwa saat mempersiapkan diri dan menggunakan atribut. Hasil yang diperoleh peserta didi menjadi dasar untuk menemukan konsep translasi, refleksi, rotasi, dan dilatasi pada pertemuan berikutnya.

\section{b. Pertemuan Kedua}

Pertemuan kedua bertujuan untuk menemukan konsep dan menentukan hasil translasi titik dan kurva. Konteks yang digunakan untuk translasi titik adalah barisan paskibra yang melakukan aba-aba 3 langkah ke kanan dan 1 langkah ke kiri. Dengan bantuan GeoGebra peserta didik dapat menemukan pola perubahan koordinat anggota paskibra. Tampak pada Gambar 2 peserta didik peroleh model of dan model for dari translasi titik. Kesimpulan 
translasi titik dan pemahaman peserta didik tentang definisi kurva menjadi titik awal pembangunan konsep translasi kurva.

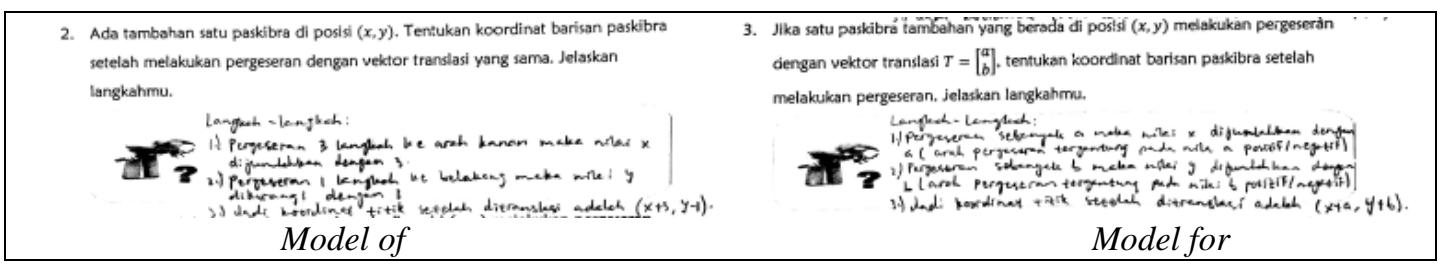

Gambar 2. Model of dan model for translasi titik

Peserta didik mengeksplorasi translasi $y=x$ dengan bantuan GeoGebra dengan beberapa vektor translasi yang ditentukan di Lembar Aktivitas. Peserta didik menemukan model untuk kasus tersebut adalah $y=x+(b-a)$. Selanjutnya pengajar mengarahkan peserta didik untuk menemukan apakah model tersebut berlaku umum. Ternyata tidak berlaku, sehingga pengajar mengarahkan untuk menemukan model yang berlaku umum dengan memanfaatkan hasil translasi titik. Peserta didik mampu menemukan model translasi kurva, yaitu $y-b=f(x-a)$.

\section{c. Pertemuan Ketiga}

Konteks yang digunakan adalah formasi unik barisan paskibra seperti Gambar 3. Berdasarkan formasi tersebut peserta didik akan menemukan koordinat pasangan anggota paskibra yang seperti objek dan bayangan saat bercermin dengan cermin $(0,0)$, sumbu $x$, sumbu $y, y=x$, dan $y=-x$. Peserta didik menemukan pola pasangan koordinat objek dan bayangan kemudian dikembangkan sampai diperoleh hubungan kedua koordinat dalam bentuk persamaan matriks. Hal ini menunjukkan bahwa peserta didik telah mengembangkan model dari level situasional menjadi level formal.

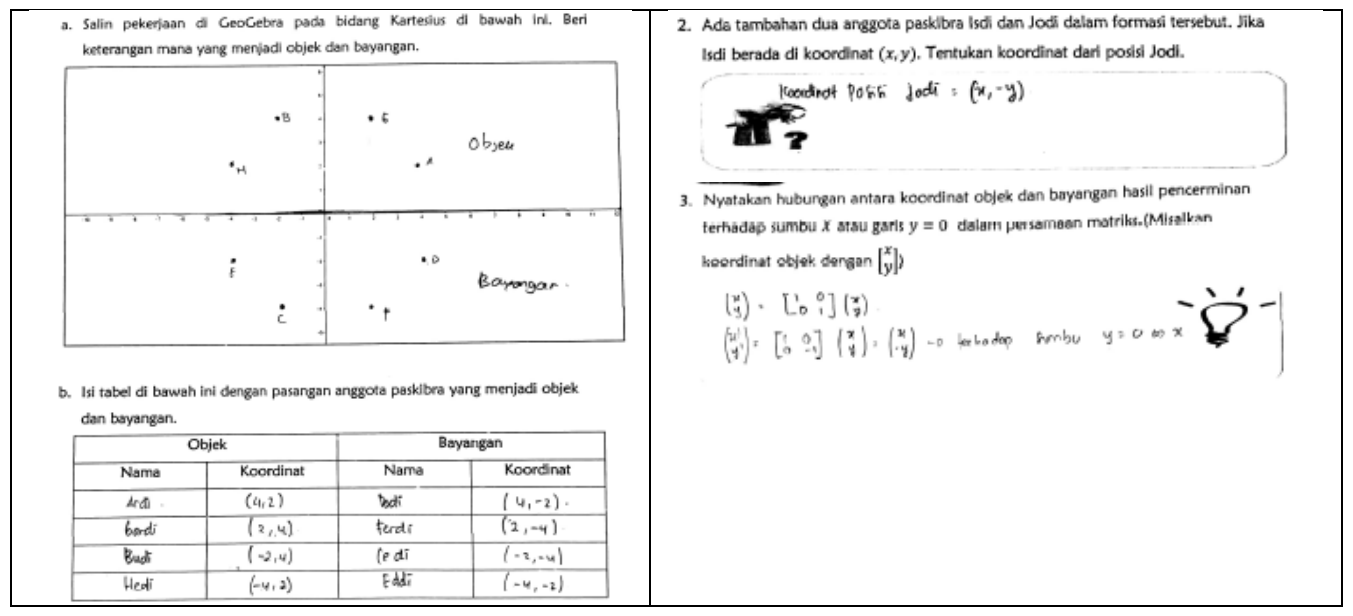

Gambar 3. Hasil diskusi Lembar Aktivitas Refleksi Terhadap Sumbu x

Prima, Vol. 3, No. 2, Juli 2019, 85-102. 


\section{d. Pertemuan Keempat}

Pertemuan keempat memuat serangkaian aktivitas untuk membangun pemahaman konsep peserta didik mengenai refleksi kurva. Sama seperti kegiatan refleksi titik, aktivitas refleksi kurva terdiri dari lima bagian tergantung dari cermin yang digunakan, yaitu titik asal $(0,0)$, Sumbu $X$, Sumbu $Y$, garis $y-x$, dan garis $y-=x$. Konteks yang digunakan adalah pengetahuan dan pemahaman yang telah dimiliki peserta didik mengenai kurva yang merupakan himpunan tak berhingga titik. Oleh karena itu jika titik dapat direfleksikan maka kurvapun juga bisa. Konsep yang berlaku pada refleksi titik juga berlaku pada refleksi kurva. Sama halnya dengan translasi, kurva dapat ditranslasikan sehingga kurva dapat direfleksikan.

Pada setiap bagian, peserta didik akan melakukan eksplorasi berbantuan GeoGebra mengenai refleksi tiga kurva $y=x+2, y=x^{2}$, dan $(x+2)^{2}+(y-3)^{2}=4$ terhadap cermin yang ditentukan. Berdasarkan persamaan bayangan kurva yang diperoleh dari GeoGebra serta dengan mempertimbangkan perubahan koordinat pada refleksi titik, peserta didik menemukan bentuk umum persamaan kurva bayangan untuk setiap kasus refleksi dengan cemin yang berbeda.

\section{e. Pertemuan Kelima}

Kegiatan pada pertemuan kelima adalah aktivitas menemukan konsep dan hasil dari rotasi titik. Rotasi titik yang dipelajari oleh peserta didik hanya rotasi dengan pusat $(0,0)$ sudut putaran $90^{\circ}, 180^{\circ}, 270^{\circ}$ searah atau berlawanan arah jarum jam. Konteks yang digunakan adalah barisan paskibra yang terdiri dari lima orang melakukan aba-aba haluan kiri. Peserta didik dapat menemukan bahwa ketika haluan kiri, pusat rotasi adalah anggota paskibra yang ada di paling kiri barisan tersebut, besar sudut rotasinya $90^{\circ}$, dan arah rotasinya ke kiri atau berlawanan arah jarum jam. Begitu pula untuk dua kali haluan kiri maka besar sudut rotasinya $180^{\circ}$, dan arah rotasinya berlawanan arah jarum jam. Selanjutnya, jika tiga kali haluan kiri maka rotasinya sebesar $270^{\circ}$ berlawanan arah jarum jam atau $90^{\circ}$ berlawanan arah jarum jam. Berdasarkan pola perubahan koordinat yang diperoleh, peserta didik menemukan model for untuk rotasi titik dalam bentuk persamaan matriks sehingga matriks transformasi untuk rotasi juga ditemukan.

\section{f. Pertemuan Keenam}

Aktivitas pertemuan keenam dirancang agar peserta didik dapat menemukan konsep dan hasil rotasi kurva. Konteks yang digunakan adalah pemahaman peserta didik terkait kurva yang dapat ditranslasi dan direfleksi serta refleksi titik. Pertanyaan arahan yang ada di

Pengembangan Pembelajaran dengan Pendekatan PMRI Berbantuan Geogebra untuk Membangun 
Lembar Aktivitas pertemuan ini serupa dengan pertemuan keempat mengenai refleksi kurva. Peserta didik melakukan eksplorasi dengan bantuan GeoGebra. Peserta didik mengeksplorasi rotasi tiga kurva $y=x+2, y=x^{2}$, dan $(x+2)^{2}+(y-3)^{2}=4$. Rotasi yang dilakukan adalah $90^{\circ}$ searah jarum jam, $180^{\circ}$ searah jarum jam, dan $90^{\circ}$ berlawanan arah jarum jam dengan titik pusat rotasi $(0,0)$.

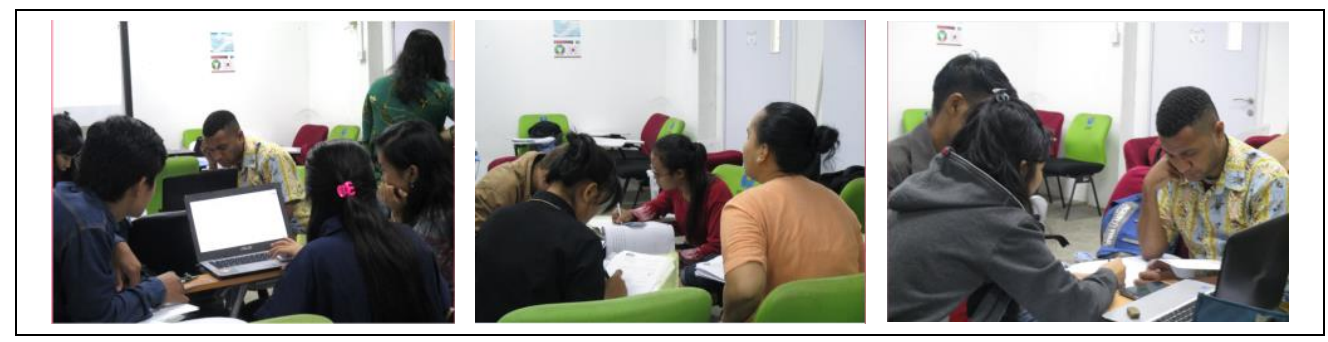

Gambar 3. Hasil diskusi Lembar Aktivitas Refleksi Terhadap Sumbu x

Berdasarkan pemahaman yang diperoleh ketika refleksi kurva, peserta didik dapat menemukan bentuk umum persamaan kurva hasil rotasi untuk setiap kasus. Hasil kerja peserta didik pada Lembar Kerjapun menunjukkan bahwa peserta didik telah dapat menggunakan model for yang ditemukan untuk menyelesaikan permasalahan rotasi kurva yang diberikan. Secara keseluruhan pemahaman konsep peserta didik mengenai rotasi kurva telah terbangun.

\section{g. Pertemuan Ketujuh}

Aktivitas pertemuan ketujuh terdiri dari serangkaian aktivitas yang membangun pemahaman konsep dilatasi bangun peserta didik. Aktivitas terbagi menjadi dua, yaitu dilatasi bangun dan eksplorasi faktor skala. Seperti pembelajaran sebelumnya, konteks yang digunakan adalah barisan paskibra. Konteks digunakan kembali agar pembangunan pemahaman konsep peserta didik dapat berkesinambungan. Permasalahan yang dimunculkan adalah barisan paskibra yang terdiri 8 orang membentuk formasi belah ketupat. Selanjutnya ada aba-aba buka formasi sedemikian sehingga setiap anggota paskibra berjarak dua kali lipat dari jarak semula terhadap tiang bendera. Terbukti dengan peserta didik yang dapat menemukan sendiri model of dari masalah yang diberikan dan juga mengembangkan model tersebut menjadi model for menggunakan operasi matriks. Dikarenakan setiap kelompok belum menuliskan model yang ditemukan dalam persamaan matriks maka pengajar memberikan arahan kepada setiap kelompok. Dari arahan pengajar, peserta didik dapat membuat model dilatasi dalam bentuk persamaan matriks seperti percakapan berikut. 
Pengajar : Sebelumnya kita tahu bahwa titik $(x, y)$ bisa dinyatakan dalam matriks. Coba bagaimana hubungannya dalam persamaan matriks?

SP1 $\quad:$ Oke bu

Pengajar : : Biasanya yang ada di ruas kiri apa?

$S P 1$

$:\left[\begin{array}{l}x^{\prime} \\ y^{\prime}\end{array}\right]$

Pengajar $\quad: Y a$

$S P 1$

$:\left[\begin{array}{l}x^{\prime} \\ y^{\prime}\end{array}\right]=k\left[\begin{array}{l}x \\ y\end{array}\right]$ begitu Ibu?

Pengajar : : Yang penting hasilnya sama

$S P 1$

: Iya, nanti sama dengan $\left[\begin{array}{l}k x \\ k y\end{array}\right]$

Pengajar : : Berarti itu pakai apa namanya?

SP1 : Perkalian skalar

Pengajar : Oke

Peserta didik membutuhkan waktu yang lebih lama ketika melakukan kegiatan kedua, yaitu eksplorasi faktor skala dilatasi. Kegiatan ini cukup menghabiskan waktu pembelajaran. Pada kegiatan ini, GeoGebra sangatlah membantu. GeoGebra memberikan bantuan visualisasi bagaimana pengaruh faktor skala dilatasi. Peserta didik menghabiskan waktu untuk menggambar di Lembar Aktivitas dan berdiskusi mengenai hasil eksplorasi. Akibatnya ada kegiatan yang belum terlaksana, yaitu mengerjakan Lembar Kerja secara Individu karena waktu pembelajaran telah habis. Oleh karena itu, pengajar mengarahkan soal pada Lembar Kerja menjadi tugas di rumah atau Pekerjaan Rumah (PR). Tugas tersebut akan dibahas pada pertemuan selanjutnya.

\section{h. Pertemuan Kedelapan}

Sebelum masuk ke aktivitas inti pertemuan delapan, perwakilan peserta didik maju membahas PR pertemuan ketujuh. Pertemuan kedelapan bertujuan untuk menemukan konsep dan menentukan hasil komposisi transformasi. Konteks yang digunakan pada pertemuan ini adalah komposisi fungsi. Selain fungsi, transformasi juga dapat dikomposisikan. Peserta didik diarahkan menemukan konsep komposisi transformasi dengan diberikan permasalahan pada Lembar Aktivitas. Permasalahan yang diberikan kepada peserta didik adalah hasil dari komposisi dua transformasi sama dengan hasil satu kali transformasi yang telah dipelajari sebelumnya. Pengajar mengarah kan pesera didik untuk menemukan konsep komposisi 
transformasi, yaitu $T_{2} \circ T_{1}\left(\left[\begin{array}{l}x \\ y\end{array}\right]\right)=M_{2} \cdot M_{1} \cdot\left[\begin{array}{l}x \\ y\end{array}\right]$. Selain itu, peserta didik menemukan bahwa perkalian matriks transformasi tersebut tidak berlaku jika pada komposisi transformasi ada translasi. Pada bagian selanjutnya, peserta didik menemukan bahwa komposisi dua transformasi juga berlaku untuk komposisi tiga transformasi atau lebih.

\section{i. Pertemuan Kesembilan}

Pertemuan kesepuluh merupakan tes pemahaman konsep transformasi geometri peserta didik. Tes terdiri dari 6 soal dimana setiap nomor mewakili indikator pemahaman konsep secara berturut-turut seperti berikut:

1) Menyatakan ulang sebuah konsep

2) Mengklasifikasikan objek menurut sifat-sifat tertentu sesuai dengan konsepnya.

3) Memberi contoh dan bukan contoh dari suatu konsep.

4) Menyajikan konsep dalam berbagai bentuk representasi matematis.

5) Memilih dan menggunakan prosedur atau operasi tertentu.

6) Mengaplikasikan konsep atau algoritma pada pemecahan masalah.

Indikator pemahaman konsep tersebut bersumber dari pendapat para ahli, yaitu Kilpatrick, Swafford, dan Findell (dalam Afrilianto, 2012), Duffin dan Simpson (dalam Kesumawati 2008), dan Peraturan Dirjen Dikdasmen Depdiknas nomor 506/C/Kep/PP/2004. Tes tersebut dikerjakan oleh peserta didik selama 120 menit.

Setelah itu, setiap peserta didik diwawancarai oleh pengajar secara bergantian untuk mengkonfirmasi kemampuan pemahaman transformasi geometri peserta didik. Dari wawancara, pengajar memperoleh penjelasan yang lebih rinci dari peserta didik tentang bagaimana menyelesaikan masalah yang diberikan untuk setiap soal. Peserta didik juga dapat mengutarakan kesulitan-kesulitan yang dihadapi ketika mengerjakan soal. Yang terpenting adalah pengajar tahu bahwa jika peserta didik menuliskan jawaban yang salah, itu bukan berarti peserta didik belum mampu memenuhi indikator kemampuan pemahaman konsep. Hal tersebut bisa dikarenakan peserta didik tidak teliti membaca soal, kurang teliti dalam manipulasi aljabar, salah perhitungan, atau karena berkendala dengan materi prasyarat. Peserta didik yang memiliki kemampuan pemahaman konsep yang baik dapat menemukan kesalahannya sendiri dan mengutarakan jawaban yang benar saat diwawancara oleh pengajar.

\section{Analisis Subjek Penelitian (SP)}

\section{a. Analisis SP1}

Di setiap pertemuan, SP1 merupakan siswa yang aktif, penggerak diskusi, dan pemimpin diskusi di kelompoknya. Hasil kerja SP1 pada tes kemampuan pemahaman konsep 
transformasi geometri menunjukkan SP1 memiliki kemampuan pemahaman konsep yang baik. Hal ini tampak dari SP1 mampu menunjukkan kemampuannya pada keenam indikator kemampuan pemahaman konsep. Namun, sifat SP1 yang kurang teliti muncul pada saat mengerjakan indikator kelima dan keenam. Akibatnya SP1 hanya mampu menyelesaikan 4 nomor dengan benar. Dua nomor yang lain kurang sempurna karena ketidaktelitian SP1. Pada saat wawancara, SP1 mampu menyadari kesalahannya sendiri. Ketika diminta oleh pengajar memperbaiki jawabannya. dengan cepat peserta didik dapat memperoleh jawaban yang benar sehingga tidak diragukan bahwa kemampuan pemahaman konsep SP1 memang baik.

\section{b. Analisis SP2}

Hasil analisis SP2 dari aktivitas setiap pertemuan, Lembar Kerja, dan Hasil Tes Kemampuan Pemahaman Konsep diperoleh bahwa kemampuan pemahaman konsep SP1 terbangun dengan baik seperti SP1. SP2 memiliki kelebihan dalam tekun menyelesaikan masalah, teliti, dan tidak terburu-buru. SP2 memperoleh skor sempurna karena mampu mnyelesaikan semua soal dengan benar. Kemampuan menjelaskan pemecahan suatu masalah juga sangat baik yang mengindikasikan kemampuan pemahamannya juga baik. Pada kegiatan diskusi, SP2 merupakan penggerak diskusi dan mampu memimpin diskusi dalam kelompoknya.

\section{c. Analisis SP3}

Pemahaman konsep peserta didik telah tumbuh. Walaupun belum sebaik SP1 dan SP2. SP3 mampu memahami konsep dasar transformasi geometri. Hal ini tampak dari SP3 yang mampu menjelaskan transformasi geometri untuk objek yang sederhana. Berdasarkan hasil tes kemampuan pemahaman konsep, SP5 mampu menyelesaikan dengan benar 2 dari 6 soal yang diberikan. SP3 tidak mengerjakan soal keempat. Tiga soal yang lain dikerjakan tetapi ada kesalahan dalam pengerjaannya akibat tidak teliti membaca soal, kesulitan mencari persamaan kurva bayangan, dan kurang teliti dalam berhitung.

\section{d. Analisis SP4}

SP4 dahulu merupakan anggota paskibra, sehingga konteks pembelajaran sangat mengena bagi peserta didik. Pemahaman konsep transformasi SP4 berkembang dengan baik. Pada aktivitas pembelajaran, SP4 mampu melakukan proses self develop model dan guided reinvention. Peserta didik dapat menemukan konsep dasar sehingga dapat berdiskusi dan bertukar pikiran dengan rekan sekelompok. SP4 termasuk peserta didik yang tekun menuliskan langkah demi langkah manipulasi aljabar ketika mencari persamaan kurva 
bayangan. Berdasarkan hasil tes kemampuan pemahaman konsep, SP4 berhasil menyelesaikan dengan benar 4 dari 6 soal yang diberikan. SP4 pada dasarnya mampu memberikan contoh dan bukan contoh suatu konsep tetapi sayangnya SP4 tidak menjawab sesuai kriteria soal karena kurang teliti membaca soal. SP4 kekurangan waktu untuk menyelesaikan soal terakhir.

\section{e. Analisis SP5}

Pembelajaran dengan pendekatan PMRI berbantuan GeoGebra dapat menumbuhkan kemampuan konsep SP5. Selain itu, penggunaan konteks dan interaktivitas dalam PMRI membuat keaktifan SP5 meningkat. Pembelajaran juga dapat dimengerti SP5 karena konteks yang konkrit bagi peserta didik dan adanya bantuan GeoGebra. Berdasarkan hasil kerja SP6 pada tes kemampuan pemahaman konsep, SP6 mampu menyelesaikan 2 soal secara sempurna yang berati SP6 mampu menyatakan ulang sebuah konsep yang telah dipelajari dan memberikan contoh serta bukan contoh yang berhubungan dengan suatu konsep. SP5 berusaha menyelesaikan empat soal yang tersisa namun belum berhasil menjawab dengan benar sempurna. Contohnya, SP5 mampu menyajikan konsep translasi garis dalam bentuk sketsa tetapi melakukan kesalahan operasi aljabar dalam menentukan persamaan kurva bayangan.

\section{f. Analisis SP6}

Pembelajaran dengan pendekatan PMRI dan GeoGebra mempermudah SP6 untuk belajar. Interaktivitas dan penggunaan konteks membuat SP6 lebih aktif di kelompok maupun di kelas. SP6 juga terlibat dalam proses penemuan untuk materi-materi tertentuan yang mampu dipahami peserta didik. Berdasarkan hasil kerja SP6 pada tes kemampuan pemahaman konsep, SP6 mampu menyelesaikan 2 dari 6 soal yang diberikan. SP6 mampu menyatakan ulang sebuah konsep yang telah dipelajari, mengklasifikasikan objek menurut sifat-sifat tertentu sesuai dengan konsep, dan memberikan bukan contoh dari suatu konsep. Dengan demikian, pemahaman konsep transformasi peserta didik mulai tumbuh.

\section{Analisis Karakteristik PMRI}

\section{a. Penggunaan Konteks}

Pada pembelajaran, konteks digunakan sebagai titik awal pembangunan konsep peserta didik. Konteks yang digunakan merupakan situasi atau kejadian yang dapat dibayangkan oleh peserta didik. Jika suatu konteks dapat dibayangkan maka peserta didik dapat melakukan proses matematisasi dengan bekerja dalam konteks. Semakin real suatu konteks maka 
semakin mudah peserta didik memahami materi pembelajaran yang berhubungan dengan konteks.

Berkaitan dengan hal tersebut, konteks yang digunakan dalam penelitian ini adalah Peraturan Baris-Berbaris (PBB) atau yang sering dikenal dengan aba-aba yang dilakukan oleh Resimen Mahasiswa (Menwa) atau Pasukan Pengibar Bendera (Paskibra). Konteks ini tidak asing bagi peserta didik karena telah dipraktekkan sejak Sekolah Dasar. Ada beberapa peserta didik yang pernah menjadi anggota Paskibra di sekolahnya dahulu di daerah asal mereka, yaitu Kepulauan Yapen, Papua dan Kupang, Nusa Tenggara Timur.

Aba-aba yang dilakukan baik Menwa atau Paskibra membantu peserta didik menemukan sifat, model of, dan juga model for dari transformasi geometri. Beberapa aba-aba dipilih sebagai konteks transformasi geometri. Aba-aba langkah ke depan, belakang, kanan, dan kiri untuk translasi dan haluan kiri serta haluan kanan untuk rotasi. Selanjutnya aba-aba setengah lengan lencang kanan, lencang kanan, dan buka formasi merupakan aba-aba yang dipilih untuk konteks dilatasi. Sementara itu, refleksi menggunakan konteks kegiatan bercermin yang dilakukan Menwa saat bersiap menggunakan atribut dan formasi unik pencerminan yang digunakan pada pertemuan ketiga. Selanjutnya setelah peserta didik paham mengenai sifat dan konsep dasar transformasi titik, maka apa yang dipahami dan dapat dibayangkan peserta didik tersebut menjadi konteks untuk transformasi kurva dan komposisi transformasi.

Penggunaan konteks tersebut memberikan dampak yang positif pada aktivitas dan cara berpikir peserta didik dalam melakukan self develop model dan guided reinvention transformasi geometri. Penggunaan konteks membuat aktivitas pembelajaran matematika menyenangkan, peserta didik lebih aktif, dan materi matematika tidak menjadi suatu hal yang abstrak bagi peserta didik.

\section{b. Penggunaan Model Matematika Progresif}

Model menjadi jembatan pengetahuan dari siatuasi konkret menuju matematika formal. Peserta didik menggunakan GeoGebra sebagai alat bantu dalam melakukan proses pengembangan model. GeoGebra menyediakan tools transformasi geometri yang lengkap, yaitu translasi, refleksi, rotasi, dan dilatasi. Peserta didik akan menggambarkan koordinat posisi anggota Paskibra sebelum dan sesudah aba-aba dengan bantuan tools GeoGebra kemudian menyalin hasil yang diperoleh ke Lembar Aktivitas. Peserta didik mengembangkan model of dari perubahan koordinat anggota Paskibra dengan menentukan posisi seorang anggota Paskibra yang koordinat awalnya adalah $(x, y)$. Selanjutnya peserta didik 
menggunakan model of yang diperoleh untuk menemukan model for transformasi geometri dalam persamaan matriks.

Untuk kurva, peserta didik melakukan eksplorasi beberapa kurva dengan bantuan GeoGebra sehingga diperoleh persamaan kurva hasil transformasi atau sering disebut kurva bayangan. Selanjutnya peserta didik membuat model of dari persamaan kurva dengan memanfaatkan hasil eksplorasi. Kebenaran model of akan dicek menggunakan GeoGebra. Berdasarkan model of dan konsep transformasi titik, peserta didik membuat model for persamaan kurva bayangan.

\section{c. Pemanfaatan Hasil Konstruksi Siswa}

Pembelajaran transformasi geometri dengan pendekatan PMRI berbantuan GeoGebra terdiri dari serangkaian aktivitas yang dilakukan peserta didik untuk mengkonstruksi pemikiran sendiri guna menemukan konsep dalam bentuk matematika formal. Aktivitas tersebut diantaranya adalah penayangan video baris-berbaris oleh Menwa kemudian perwakilan peserta didik mempraktikkan aba-aba baris-berbaris sedangkan peserta didik lain mengamati dengan seksama. Hasil praktik dan pengamatan yang diperoleh peserta didik digunakan untuk mengkonstruksi pemikiran mengenai sifat-sifat transformasi geometri. Selanjutnya sifat-sifat transformasi geometri yang diperoleh sebelumnya dimanfaat sebagai konsep dalam menentukan model of transformasi geometri. Hasil model of yang dikonstruksi sendiri peserta didik dimanfaatkan kembali dalam menemukan model for. Selain itu hasil konstruksi peserta didik pada pertemuan kedua mengenai rotasi titik dimanfaatkan kembali pada pertemuan ketiga untuk menemukan konsep rotasi kurva. Hal ini juga berlaku untuk rotasi, refleksi, dilatasi dan komposisi transformasi.

\section{d. Interaktivitas}

Interaktivitas yang terjadi dalam pembelajaran bermanfaat bagi peserta didik untuk membangun pemahaman konsep. Melalui diskusi kelompok dan diskusi kelas terjadi interaksi antara peserta didik dengan peserta didik maupun antara peserta didik dengan pengajar. Peserta didik dapat mengemukakan pendapat yang ia miliki dari pemahaman yang ia peroleh. Semakin banyak pendapat dari peserta didik dapat memperkaya pemahaman peserta didik dalam proses diskusi. Pertukaran pengetahuan juga terjadi dalam diskusi. Masing-masing peserta didik terlibat aktif dalam kegiatan diskusi yang terjadi dalam pembelajaran. Hal ini dapat meningkatkan keaktifan peserta didik.

Pengajar sebagai fasilitator bertugas mengarahkan diskusi peserta didik dalam meramu pengetahuan yang dimiliki peserta didik sehingga memungkinkan terjadinya guided 
reinvention transformasi geometri maupun penyelesaian masalah yang diberikan di Lembar Aktivitas. Interaktivitas antara pengajar dan peserta didik berjalan dengan baik. Pendidik juga memberikan penguatan serta apresiasi terhadap pendapat atau hasil pemikiran peserta didik baik yang salah maupun yang benar sehingga peserta didik dapat kembali mengkonstruksi pemikirannya sehingga terjadi penemuan.

\section{e. Keterkaitan}

Konsep-konsep dalam matematika tidak berdiri sendiri melainkan saling terkait. Pemahaman peserta didik mengenai suatu konsep akan digunakan kembali ketika mempelajari konsep lain yang lebih tinggi tingkatannya. Peserta didik akan lebih baik memahami konsep tingkat tinggi jika pemahaman konsep dasarnya juga baik. Materi transformasi geometri yang dipelajari dengan pendekatan PMRI berbantuan GeoGebra berkaitan erat dengan konsep sistem koordinat, vektor, matriks, persamaan kurva, komposisi fungsi, dan operasi aljabar. Konsep-konsep inilah yang perlu dipahami peserta didik dengan baik agar dapat mempelajari transformasi geometri dengan baik pula. Keterkaitan konsepkonsep tersebut mempengaruhi terbangunnya pemahaman konsep peserta didik.

\section{SIMPULAN DAN SARAN}

Berdasarkan hasil analisa retrospektif dan analisis data terhadap kemampuan pemahaman konsep transformasi geometri dapat disimpulkan bahwa penerapan pendekatan PMRI berbantuan Geogebra menumbuhkan dan meningkatkan pemahaman konsep transformasi geometri peserta didik dalam pembelajaran.

Penggunaan konteks Peraturan Baris-Berbaris (PBB) atau aba-aba baris-berbaris yang dilakukan oleh Menwa atau Paskibra merupakan suatu hal yang tidak asing bagi peserta didik STKIP Surya sehingga memberikan dampak positif terhadap pemahaman konsep transformasi geometri peserta didik. Penggunaan konteks membuat peserta didik mengetahui bahwa matematika ada dalam aktivitas kehidupan sehari-hari. Selain itu, konteks juga membuat materi transformasi geometri menjadi konkrit bagi peserta didik.

Aktivitas menentukan koordinat anggota Paskibra sebelum dan sesudah melakukan aba-aba baris-berbaris serta eksplorasi dengan bantuan GeoGebra membantu peserta didik untuk memvisualisasikan konsep transformasi geometri. Konsep perubahan yang ditemukan peserta didik digunakan untuk membuat model of dari permasalahan yang diberikan. Kemudian peserta didik mengembangkan model of menjadi model for transformasi geometri. 
Adanya model of dan model for menjadi jembatan penghubung konteks dunia nyata dan matematika formal bagi peserta didik.

Konstruksi pemikiran yang dilakukan peserta didik di setiap pembelajaran menunjukkan bahwa pembelajaran dengan PMRI membuat peserta didik tidak menempatkan matematika sebagai produk jadi melainkan sebagai bentuk aktivitas atau proses. Peserta didik tidak diposisikan sebagai penerima produk jadi tetapi sebagai tokoh dalam penemuan kembali konsep yang mampu menyelesaikan masalah.

Interaktivitas yang terjadi tidak hanya antara pengajar dan peserta didik tetapi juga antara peserta didik dengan peserta didik dalam diskusi kelompok maupun diskusi kelas. Melalui diskusi peserta didik terjadi pertukaran pengetahuan yang memperkaya pemahaman guna menemukan kembali konsep matematika. Pembelajaran PMRI menempatkan peserta didik sebagai pusat pembelajaran dimana peserta didik terlibat aktif dalam penemuan konsep matematika formal sedangkan pengajar sebagai fasilitator dan motivator peserta didik dalam proses penemuan.

Keterkaitan (intertwinment) dalam pembelajaran transformasi geometri adalah konsepkonsep yang telah dipelajari sebelumnya meliputi sistem koordinat, vektor, matriks, persamaan kurva, komposisi fungsi, dan operasi aljabar.

\section{DAFTAR PUSTAKA}

Afrilianto, M. (2012). Peningkatan Pemahaman Konsep dan Kompetensi Strategis Matematis Siswa SMP dengan Pendekatan Metaphorical Thinking. Jurnal Ilmiah Program Studi Matematika STKIP Siliwangi Bandung,1(2). Accessed on November 4, 2017 from http:// e-journal.stkipsiliwangi.ac.id /index.php/infinity/article/view/19/18.

Albab, I. U., Hartono, Y., \& Darmawijoyo. (2014). Kemajuan Belajar Siswa Pada Geometri Transformasi Menggunakan Aktivitas Refleksi Geometri. Cakrawala Pendidikan, 33(3). Accessed on January 20, 2015 from http: https://media.neliti.com/media/publications /87094-ID-kemajuan-belajar-siswa-pada-geometri-tra.pdf.

Alfled, P. (2004). Peter Alfled's Home Page-Understanding Mathematics. Accessed on January 21, 2015 from http://www.math.utah.edu/ pa/math.html.

Bakker, Arthur, \& Eerde, Dolly van. (2013). An Introduction to Design-Based Research With an Example from Statistics Educations. Acessed on June 17, 2017 https://www.researchgate.net/publication/256618979_An_Introduction_to_DesignBased_Research_with_an_Example_From_Statistics_Education. 
Gravemeijer, K., \& Eerde, D. v. (2009). Design Research as a Means for Building a Knowledge Base for Teachers and Teaching in Mathematics Education. The Elementary School Journal, 109(5). Acessed on December 2, 2017 from http://www.fi.uu.nl/publicaties/literatuur/7287.pdf.

Guven, B. (2012). Using Dynamic Geometry Software to Improve Eight Grade Student's Understanding of Transformation Geomatry. Australasian Journal of Educational Technology, 2(28). Acessed on January 20, 2015 from https://pdfs.semanticscholar.org/5c8f/5b633b257689be852f192c 834a5fc4de8d1b.pdf

Hollebrands, K. F. (2004). High School Student's Intuitive Understandings of Geometric Transformations. Mathematics Teacher, 97(3). Acessed on March 8, 2017 from http://www.nctm.org.

Kesumawati, N. (2008). Pemahaman Konsep Matematik dalam Pembelajaran Matematika. Prosiding Seminar Nasional Matematika dan Pendidikan Matematika. Acessed on July 1, 2017 from http://eprints.uny.ac.id/6928/.

Larijani, M. M., Karimi, S., Mal Khalifeh, M. R., \& Ahmad, S. (2012). Study the Efficiency of GeoGebra Software in Better Understanding of Mathematical Concept. International Journal of Emerging trends in Engineering and Development, 4. Acessed on April 17, 2014 from https://rspublication.com/ijeted/may-12/98.pdf.

Minnesota STEM Teacher Center. (2014). Acessed on March 12, 2016 from http://www.scimathmn.org/stemtc/frameworks/433-geometric-transformations

Novrika, Dina, Putri, R. I. I., \& Hartono, Yusuf. (2016). Desain Pembelajaran Materi Refleksi Menggunakan Motif Kain Batik Untuk Siswa Kelas VII. Prosiding Seminar Matematika dan Pendidikan Matematika, 607-626.

Nugraheni, Esti Ambar \& Sugiman. (2013). Pengaruh Pendekatan PMRI terhadap Aktivitas dan Pemahaman Konsep Matematika Siswa SMP. PYTHAGORAS: Jurnal Pendidikan Matematika, 8(1).

Özerem, A. (2012). Misconceptions In Geometry And Suggested Solutions For Seventh Grade Students." International Journal of New Trends in Arts, Sports \& Science Education, 1(4). Acessed on February 28, 2014 from https://www.sciencedirect.com/science/article/pii/S1877042812040190.

Plomp, Tjeerd.(2013). Educational Design Research: An Introduction. Enschede: Netherlands for Curiculum Development (SLO) 
Saha, R. A., Mohd. Ayub, A. F., \& Tarmizi, R. A. (2010). The Effects of GeoGebra on Mathematics Achievement: Enlightening Coordinate Geometry Learning. International Conference on Mathematics Education Research (ICMER), 686-693. Acessed on Juni 23, 2014 from https://core.ac.uk/download/pdf/82664417.pdf. 